\title{
Monitoring Water Resources over the Kotmale Reservoir in Sri Lanka Using ENSO Phases
}

\author{
Sewwandhi Chandrasekara, ${ }^{1}$ Venkatraman Prasanna, ${ }^{2}$ and Hyun-Han Kwon ${ }^{1}$ \\ ${ }^{1}$ Chonbuk National University, Jeonju, Republic of Korea \\ ${ }^{2}$ National Institute of Meteorological Sciences, Jeju, Republic of Korea \\ Correspondence should be addressed to Venkatraman Prasanna; prasa_arnala@yahoo.com
}

Received 28 February 2017; Revised 29 May 2017; Accepted 6 July 2017; Published 17 August 2017

Academic Editor: Panuganti C. S. Devara

Copyright (c) 2017 Sewwandhi Chandrasekara et al. This is an open access article distributed under the Creative Commons Attribution License, which permits unrestricted use, distribution, and reproduction in any medium, provided the original work is properly cited.

\begin{abstract}
In this study, the El Nino Southern Oscillation (ENSO) phase index is used for water management over the Kotmale reservoir in Sri Lanka. Daily rainfall data of 9 stations over the Kotmale catchment during 1960-2005 June-September (JJAS) season is investigated over the Kotmale catchment. The ENSO phases are identified based on the $0.5^{\circ} \mathrm{C}$ sea surface temperature (SST) anomaly over Nino 3 region. The study has brought out few stations showing increasing and a few decreasing seasonal rainfall trends for JJAS season, while there is no change in the annual rainfall for the catchment. Monthly and seasonal rainfall of all the selected stations showed negative correlation with the sea surface temperature (SST) over the Nino-3 region index during JJAS season with varying magnitudes. During the warm phase of ENSO, below average rainfall is prominent for JJAS season over many stations. The rainfall especially during early September showed a significant below average rainfall during the warm ENSO phase. The seasonal rainfall during neutral and cold ENSO phases does not experience similar significant changes as seen during warm ENSO phase. Inflow of the Kotmale reservoir shows decreasing trend for the period of 1960-2005 in the observation from all stations collectively.
\end{abstract}

\section{Introduction}

Climate change and variability have considerable attention from the scientific community in the recent decades and numerous studies on this topic have led to a better understanding of various climate phenomena and their driving mechanisms. The term teleconnection refers to large and persistent ocean-atmospheric anomaly patterns (El-Nino Southern Oscillation (ENSO), North Atlantic Oscillation (NAO), Madden Julian Oscillation (MJO), etc.) over larger areas, and apparent causal effects on regional climatic conditions in the adjacent or remote regions. Due to the unique location of Sri Lanka (close to Equator and within the movement of Inter Tropical Convergence Zone (ITCZ)), the rainfall of Sri Lanka is affected by the various oscillations observed in the Indian Ocean and the Pacific Ocean the through changes in the atmosphere [1].

The ENSO phenomenon is one of the primary modes of seasonal climate variabilities, particularly in the tropics [24]. ENSO is a shift in the pattern of oceanic warming and atmospheric circulation centered in the Pacific Ocean with implications across the tropics that recurs typically 2-7 years apart. Many studies showed ENSO influences on rainfall over Sri Lanka [2, 5-9]. Suppiah [10, 11], Malmgren et al. [12], and Prasanna and Yasunari [9] found that there is a strong link between seasonal rainfall anomalies and the ENSO events over Sri Lanka. The phases of the ENSO phenomena associated with warmer and colder than normal sea surface temperature in the equatorial Central and Eastern pacific oceans are referred to as El Nino and La Nina, respectively. Recently, Prasanna and Yasunari, [9] found that, apart from the ENSO effect, Indian Ocean Dipole mode (IOD) also impacts Sri Lanka and the South peninsular India during the months of October, November, and December (OND) Season, since the IOD impact is strongest in the months of September, October, and November (SON). They have also shown the asymmetrical influence of positive and negative mode of IOD on Sri Lanka and South peninsular Indian monsoon during the OND season. 


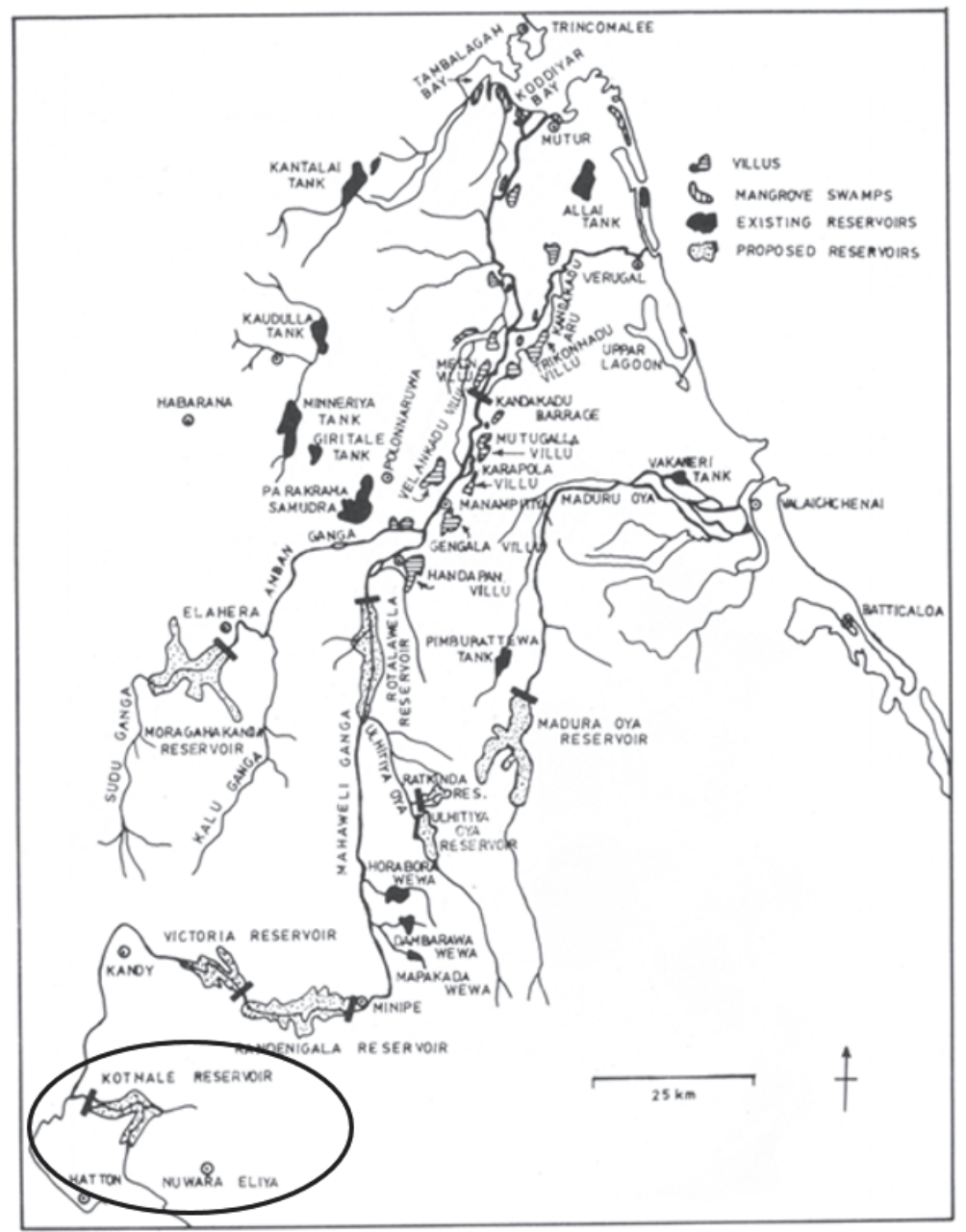

FIgURE 1: Location of the Kotmale reservoir in Sri Lanka. Source: Food and Agriculture Organization of the United Nation [22].

The rainfall of Sri Lanka and India becomes weak during El Nino episodes in the boreal summer due to large-scale subsidence over the Central Indian Ocean region and enhanced from October to December [3, 5, 9, 11, 13-15]. Due to the alteration in intensity and location of Walker circulation cell, the climate of Sri Lanka is impacted during ENSO extremes [16]. According to the location of Walker cell from April to September, Sri Lanka receives relatively lower rainfall during El Nino and subsequently receives increased rainfall during October to December $[9,17,18]$. Since Sri Lanka is a tiny island in the vast Indian Ocean, the oceanic condition around Sri Lanka also modifies the El-Nino effect [19].

Here we investigate the viability of using ENSO index for the reservoir water management over the Kotmale reservoir in Sri Lanka as a case study. Kotmale reservoir is one of the multipurpose reservoirs created for irrigation, drinking, and hydropower generation of 445 Giga-watt hour/year [20], built in Sri Lanka in the year 1980. Storage volume of the Kotmale reservoir is vital due to various reasons. It is the uppermost reservoirs in the irrigation complex of Mahaweli Authority of Sri Lanka (MASL). The variability of storage volume in Kotmale affects the irrigation and hydropower generation on the downstream cascade of reservoirs (Figure 1). Kotmale reservoir is regulated by discharging the water to increase the flow diversion at the Polgolla barrage into the downstream cascade reservoirs for augmenting the irrigation supply and hydropower generation. The Kotmale reservoir reduces flood peaks and their frequency, thus alleviating the floods in the Gampola area below it [21].

However the original volume of 176.78 million cubic meters (Maximum capacity) has an average annual loss of $0.23 \%$ due to the formation of sediments $[23,24]$. Further eutrophication is also experienced just five years after completion of the Kotmale reservoir, due to eroded soil nutrients from tea plantation in the catchment area [24]. Although the reservoir inflow is higher during June to November compared to other months of the year [25, 26] (Figure 2), in the recent decades the reservoir storage reduced down to dead storage level of the reservoir during August and September. Even the ruins of ancient territory which are submerged under the waters of Kotmale reservoir are seen during these recent dry seasons, when the water levels are low [27]. Therefore, it is vital to manage water storage of the Kotmale reservoir efficiently and effectively to satisfy the 


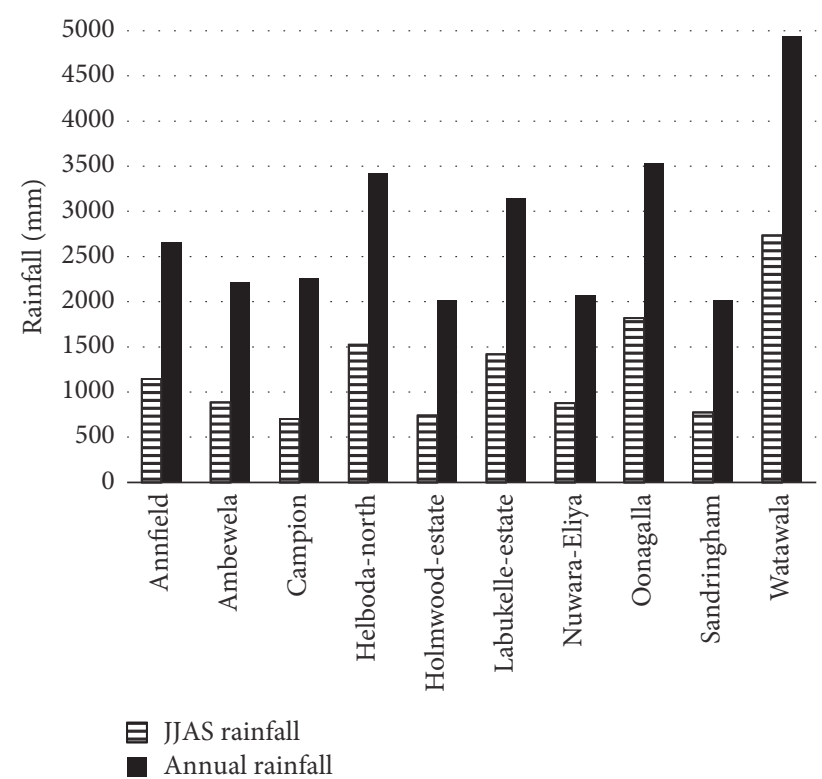

FIGURE 2: Contribution of rainfall during JJAS season to annual rainfall for the stations.

water demands. Therefore understanding the teleconnection of ENSO on the rainfall over the catchment area can be useful to build a new water management strategy to Kotmale reservoir.

\section{Data and Method}

Daily rainfall data of 11 meteorological stations are used in this study (Table 1). The rain gauges are managed by the Department of Meteorology, Sri Lanka. The Department personnel inspect these gauges, archive the data, and undertake quality control of it regularly [28]. We have undertaken further quality test for this data, like identification of outliers, cross checks for extreme values, checks for drifts in the data, and cross correlation analysis. Daily climatology of the screened rainfall stations is plotted to analyze the monthly rainfall variations for each station. Time series analysis of rainfall is carried out for each station for the JJAS season.

Inflow data of Kotmale reservoir for the duration from 1984 to 2012 is also collected from Mahaweli Authority of Sri Lanka (MASL). MASL calculates the inflow to the Kotmale reservoir by applying the following method. Water volume of the reservoir is calculated using the remaining water level of the reservoir from its original capacity, after sustaining the removals for hydropower generation. Using contour gridding of the reservoir, the inflow is back-calculated from the remaining water level.

The sea surface temperature (SST) values are extracted from the Japan Meteorological Agency website. Data are available at ftp://www.coaps.fsu.edu/pub/JMA_SST_Index/. SST anomalies of Nino 3 index are prepared to identify warm, cold, and neutral ENSO phases.

Mean SST values are correlated with the mean monthly rainfall values for each station for JJAS season. Nuwara Eliya
TABLE 1: Rainfall stations used for the study and duration of the data.

\begin{tabular}{lc}
\hline Duration of available data & Station name \\
\hline $1900-1961$ (62 years) & Nuwara Eliya \\
$1961-1974$ (14 years) & Hope-estate \\
$1961-1989$ (29 years) & Oonagalla-estate \\
$1961-1996$ (36 years) & Watawala \\
$1961-2000$ (40 years) & Ambewela, Holmwood-estate \\
$1961-2005$ (45 years) & Annfield, Campion, \\
& Helboda-north, Labukele-estate, \\
& Sandringham \\
\hline
\end{tabular}

station is eliminated from the SST analysis, because only the rest of the 9 stations have data between 1960 and 2005 . This analysis is done to find whether there is a relationship between SST and the selected rainfall stations. Pentad daily rainfall data are also created for each ENSO phase. Finally, the rainfall anomalies of each station are examined for different ENSO phases to understand the variability of rainfall over the catchment area.

\section{Results and Discussion}

3.1. Quality Assessment of Station Data. Among the 11 station datasets, almost all the data contained precipitation anomalies in the range of -0.5 to $0.5 \mathrm{~mm} /$ day. All stations show a similar precipitation anomaly and root mean square error (RMSE), except for Ambewela and Nuwara Eliya. Ambewela and Nuwara Eliya stations show significant deviation in anomalies during 1994 and 1924 to 1927. All the stations exhibit a tendency of having low variance and the absence of extreme outliers.

However, Hope Estate station exhibits a significant lower value of correlation with other 10 stations. Furthermore, Hope station does not show significant correlation between the JJAS seasonal rainfall of the Annfiled and Oonagalla stations, $r=0.0071, P<0.05$ and $r=-0.0205$, and $P<0.05$, respectively. This may be due to fewer years of data availability for the Hope station when compared with other 10 stations. Therefore, based on our quality assessment procedure, the Hope station is also not used for the further analysis in this study.

3.2. Rainfall Trend Analysis. According to the data, results show that the rainfall during JJAS season is responsible for 30 to $55 \%$ of annual rainfall of the study region (stations put together) or the catchment area (i.e., Campion station, $30.9 \%$ and Watawala station, 55.3\%). Figure 2 represents the contribution of rainfall during JJAS season to annual rainfall for each station.

We identified four distinct rainfall trends (i.e., significant increasing rainfall trend, insignificant increasing rainfall trend, significant decreasing rainfall trend, and insignificant decreasing rainfall trend) (Figure 3). Significant increasing rainfall trend is observed in Watawala and Campion stations. Insignificant increasing rainfall trend is observed in Helboda-north, Ambewela, and Oonagalla-estate stations. 
TABLE 2: List of years for different ENSO phases during JJAS season from 1960 to 2005.

\begin{tabular}{|c|c|c|}
\hline Description & Years & $\begin{array}{l}\text { Total number of } \\
\text { years }\end{array}$ \\
\hline Warm ENSO phase & $1963,1965,1972,1976,1982,1983,1987,1991,1997$ and 2002 & 10 years \\
\hline Cold ENSO phase & $1961,1964,1967,1970,1971,1973,1975,1978,1984,1985,1988$ and 1999 & 12 years \\
\hline Neutral ENSO phase & $\begin{array}{c}1960,1962,1966,1968,1969,1974,1977,1979,1980,1981,1986,1989,1990 \\
1992,1993,1994,1995,1996,1998,2000,2001,2003,2004 \text { and } 2005\end{array}$ & 24 years \\
\hline
\end{tabular}

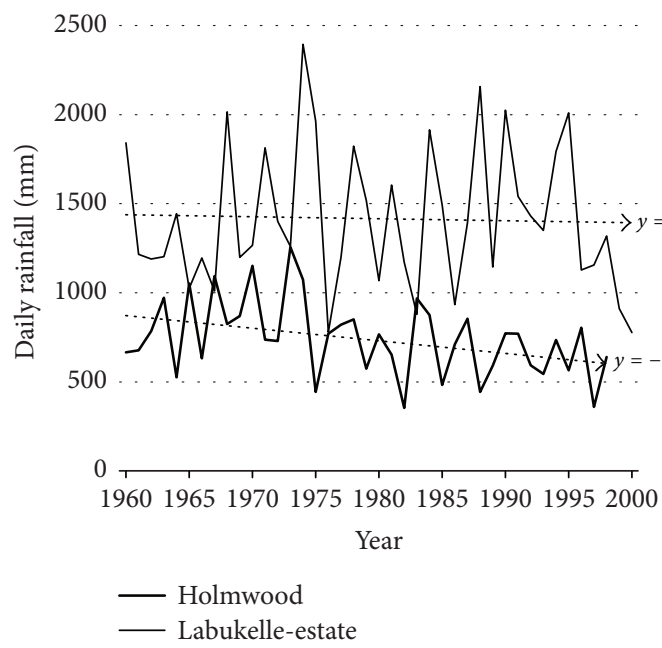

(a)

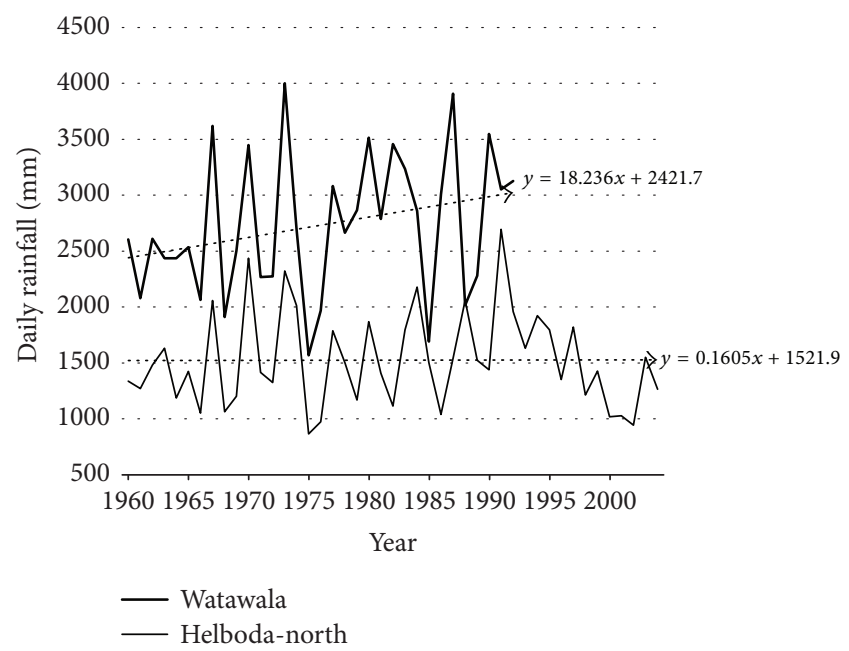

(b)

Figure 3: Holmwood and Labukelle-estate stations show decreasing rainfall trends (a) and Watawala and Helboda-north stations show increasing rainfall trends $(\mathrm{b})$.

On the other hand significant decreasing rainfall trend is observed in Nuwara Eliya, Sandringham, Annfield, and Holmwood-estate stations.

Furthermore Chandrasekara and Prasanna [29] showed that the annual rainfall of Holmwood-estate station has a high rate of decreasing trend, which is aggravated by the high level of deforestation of the southern forests of Sri Lanka $[30,31]$. Insignificant decreasing rainfall trend is observed in Labukelle-estate station. However, Chandrasekara and Prasanna [29] and Wickramagamage [32] showed that there are predominant negative trends in the annual rainfall of central highlands including the study stations. Therefore, increase in rainfall in the JJAS season has low influence on the annual rainfall of the selected stations.

3.3. Relationship with SST over Nino-3 Region. For each station, the JJAS seasonal rainfall shows negative correlation with mean SST over Nino-3 region (Figure 4) (note that Nuwara Eliya station is eliminated from the SST analysis because only the rest of the 9 stations have data in between 1960 and 2005 and Nuwara Eliya station does not match with the selected data period). As seen in Figure 3, seasonal rainfall of Holmwood-estate is highly impacted due to changes in the SST over Nino-3 region. Furthermore, Campion station has the lowest impact due to the changes in the SST over Nino-3 region. For the Holmwood-estate station, there is a significant negative relationship between the JJAS seasonal

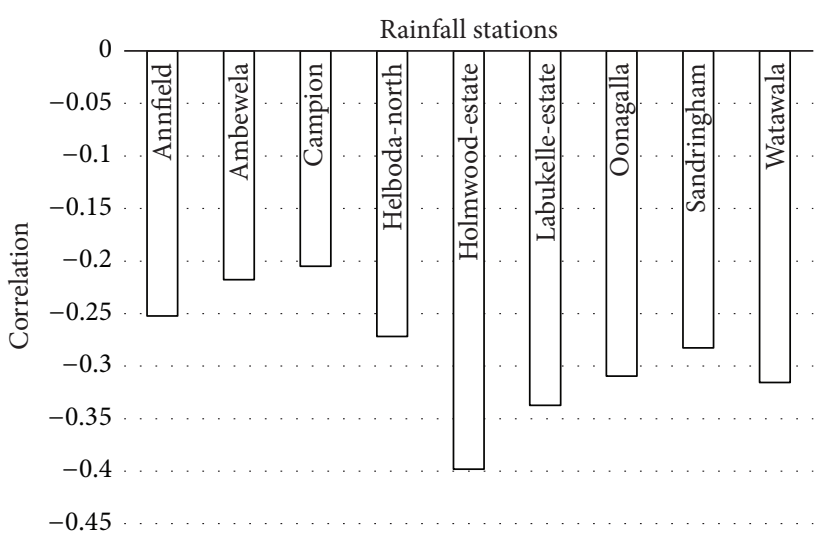

FIGURE 4: Correlation between mean SST (Nino-3 region) and JJAS mean rainfall for 9 stations.

rainfall and the SST over Nino-3 region, $r=-0.3980$ and $P<$ 0.05. Further, Labukelle-estate showed significant negative relationship between the JJAS seasonal rainfall and the SST over Nino-3 region, $r=-0.3373$ and $P<0.05$. Rest of the stations do not show statistically significant relationship between the JJAS seasonal rainfall and the SST over Nino-3 region.

Table 2 shows the periods (years), which exhibit observed warm ENSO phase, cold ENSO phase, and neutral ENSO 


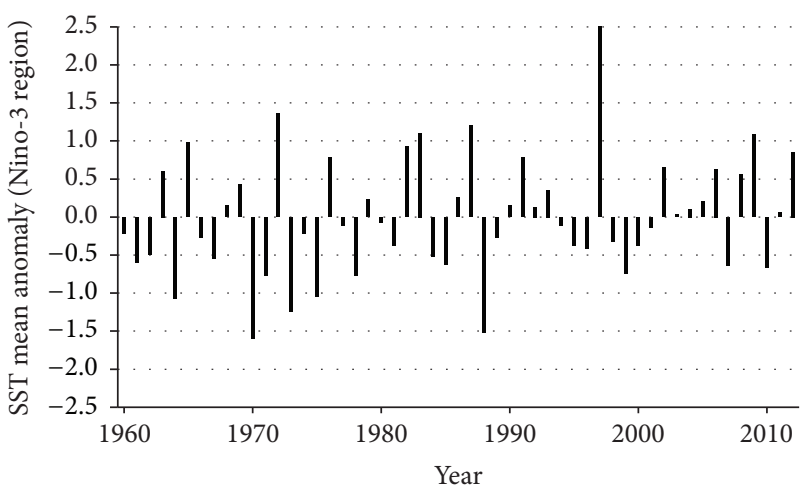

FIGURE 5: SST anomalies over Nino-3 region for JJAS season from 1960 to 2010.

phase during JJAS season from 1960 to 2005. Significant ENSO events are identified during 1982/83 and 1986/87 and the strongest event during $1997 / 98$ [19, 33]. As seen from Figure 5, during JJAS season significant warm ENSO (SST anomaly is more than $+2.5^{\circ} \mathrm{C}$ ) is observed in 1997. During 1970 and 1988, significant cold ENSO phase (SST anomaly is less than $-1.5^{\circ} \mathrm{C}$ ) is observed during JJAS season (Figure 5).

\subsection{Rainfall Characteristics over Ambewela Station (Charac-} teristics: Enhancement of Rain during Neutral ENSO Phase) in JJAS Season. For all the stations, average pentad rainfall for JJAS season during neutral ENSO phase showed similar pattern as average daily rainfall. Furthermore, all the stations showed significant above average pentad rainfall during midJune (39th pentad). However, Ambewela station showed significant above average pentad rainfall not only during mid-June (39th pentad), but also at the end of July (48th pentad) and beginning of September (55th pentad) compared to average pentad rainfall for JJAS season (Figure 6).

Labukelle-estate, Holmwood-estate, Campion, Annfield, and Watawala stations observed above average seasonal rainfall during JJAS season for neutral ENSO phase. Sandringham and Helboda-north stations showed more frequent below average seasonal rainfall events than the above average seasonal rainfall during neutral ENSO phase for JJAS season. Ambewela and Oonagalla-estate showed equal chance of having above average seasonal rainfall and below average seasonal rainfall for neutral ENSO phase.

\subsection{Rainfall Characteristics over Helboda-North Station} (Characteristics: Enhancement of Rain during Warm ENSO Phase) in JJAS Season. For all the stations, average pentad from daily rainfall for JJAS season during warm ENSO phase showed similar pattern, but with lower rainfall than average pentad rainfall. However, during mid-June (33rd pentad), early July (37th pentad), and early September (43rd pentad) was shown significant below average pentad rainfall compared to the mean pentad rainfall for the JJAS season (Figure 7). On the other hand during mid-August (52nd pentad), the average pentad daily rainfall showed more rainfall compared to average pentad daily rainfall for JJAS season.

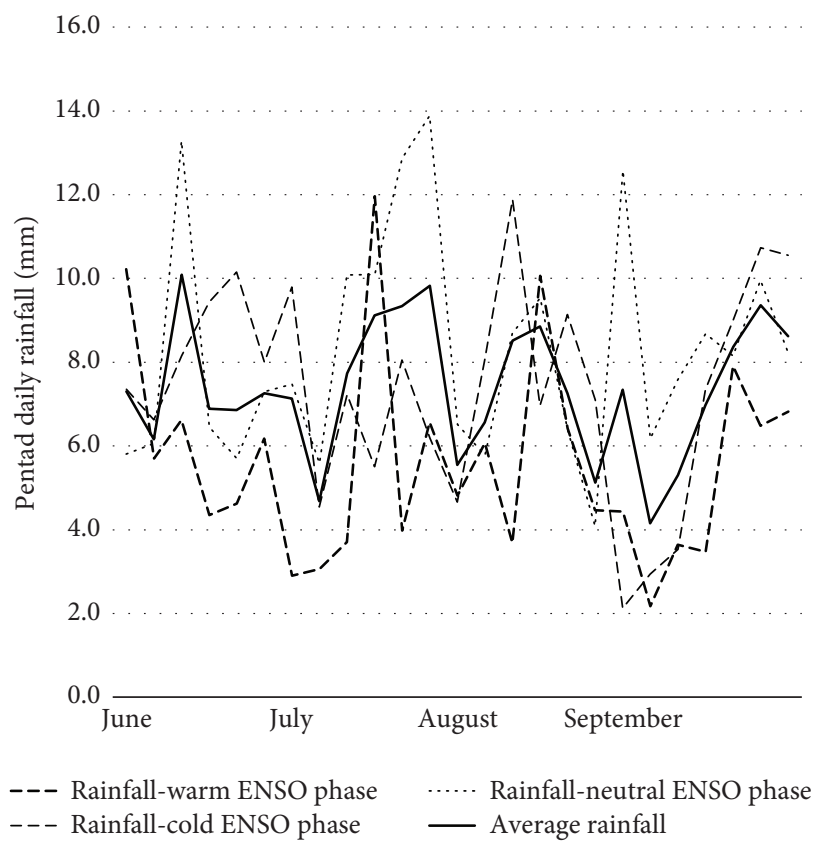

FIgURE 6: Pentad (five-day mean) rainfall changes in Ambewela station for JJAS season.

25.0

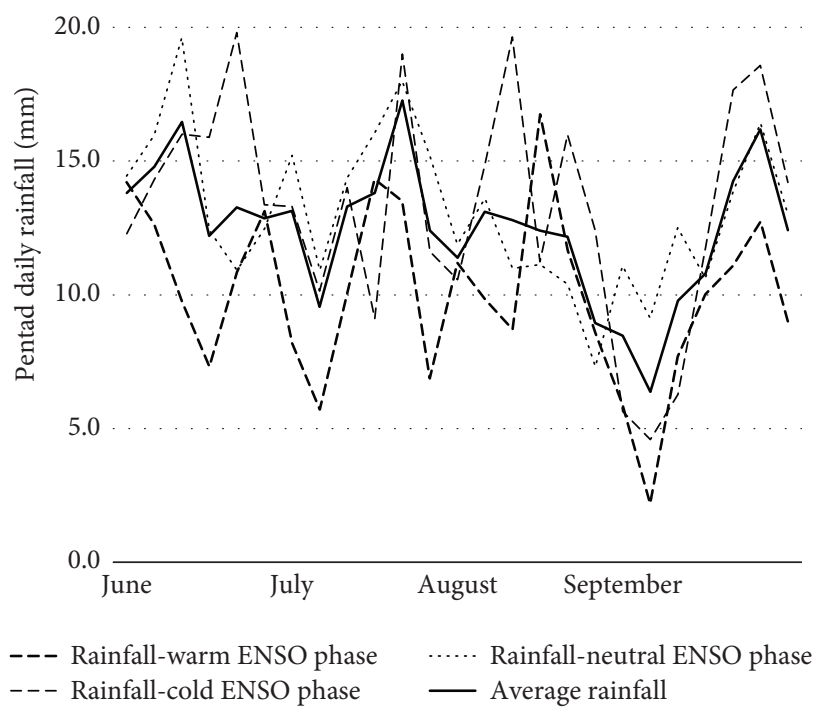

Figure 7: Pentad (from daily data) rainfall changes in Helboda-north station for JJAS season.

Sumathipala [19] mentioned that during 1982/83 ENSO event, Sri Lanka suffered severe drought condition. Our study revealed that all the stations experienced below average seasonal rainfall during 1982/83 ENSO event, except Annfield and Watawala stations; these stations showed above average seasonal rainfall during JJAS season in 1982. However, Sumathipala [19] further mentioned that during 1986/87 ENSO effect on Sri Lanka was minimal. 1986/87 ENSO event 


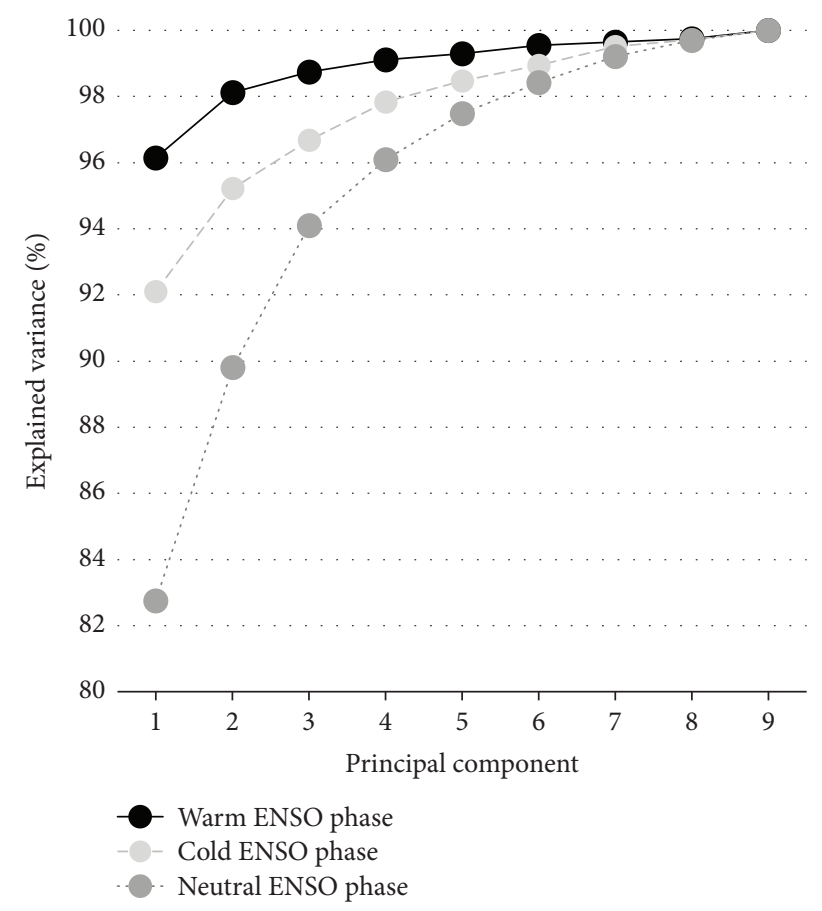

FIGURE 8: Principal components and their explained variances for the ENSO phases.

impacted below average seasonal rainfall for all the stations in 1987. However, in our study 1986 was categorized as a neutral year based on the SST data for the JJAS season. All the stations showed below average rainfall during 1997, except for Campion station (note that Oonagalla-estate and Watawala stations were not calculated because of the unavailability of rainfall data).

Ambewela, Helboda-north, Labukelle-estate, and Oonagalla-estate stations showed below average rainfall on every warm ENSO phase (Table 2) in JJAS season during 1963-2005. Holmwood-estate, Annfield, Sandringham, and Watawala stations showed below average seasonal rainfall on majority of warm ENSO phases (i.e., above average seasonal rainfall for only one ENSO warm phase for each station). Campion showed below average seasonal rainfall for all warm ENSO phases, except in 1972, 1991, and 1997.

Furthermore, Principal Component Analysis (PCA) showed that during warm ENSO phase more or less than $96 \%$ of variance is explained from first principal component of the rainfall (Figure 8). However, percentage of variance explained by first principal component of the rainfall during the cold and neutral ENSO phases is less than the warm ENSO phase. Therefore, rainfall would have more impact during warm ENSO phase than the cold and neutral ENSO phases.

Zubair [8] revealed in his study that, during El-Nino events, the rainfall between June and September declines in the Mahaweli basin. In our study, the catchment over Kotmale is a subcatchment of Mahaweli basin and our study also shows that there is a decline of rainfall during JJAS season during the warm ENSO phases. However, since Sri Lanka is

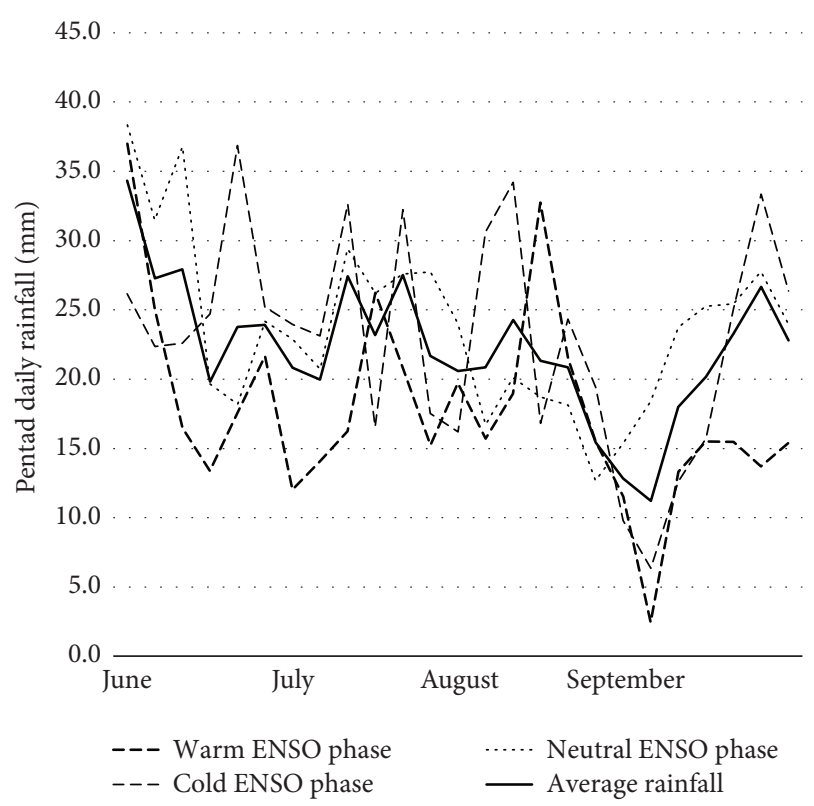

Figure 9: Pentad (from daily data) rainfall changes in Watawala station for JJAS season.

comparatively a small island, the oceanic conditions around Sri Lanka can also modify the El-Nino effects [19].

3.6. Rainfall Characteristics over Watawala Station (Characteristics: Enhancement of Rain during Cold ENSO Phase) in JJAS Season. The averaged pentad data from daily rainfall of JJAS season during cold ENSO phase depicts a similar pattern, as averaged pentad data from the daily rainfall shows a significant above average pentad rainfall during end of June (41st pentad) and mid-August (51st pentad) (Figure 9).

All the stations experienced below average seasonal rainfall during 1970 cold ENSO phase. Except for Labukelle-estate and Ambewela stations, the rest of the study stations showed above average seasonal rainfall during 1988 cold ENSO phase.

However, all the study stations have shown more or less equal chances of having both the above average and below average seasonal rainfall for cold ENSO phase in JJAS season (i.e., 50\%:50\% chance). Holmwood-estate, Oonagalla-estate, Annfield, and Helboda-north stations showed frequent above average seasonal rainfall during cold ENSO phase in JJAS season. However, Zubair [8] revealed in his study that, except for January to March, remaining months observed above average rainfall during cold ENSO phase. However, if the Sothern Oscillation Index (SOI) over Nino-3.4 region is greater than 8 (SOI index scale) for at least 5 consecutive months which is started in April or May, the Wet Zone of Sri Lanka (i.e., the study stations are within the Wet Zone of Sri Lanka) would experience above average South-west monsoon rainfall anomalies (i.e., South-west monsoon period experienced between May and September in Sri Lanka) [34].

3.7. Reservoir Water Management. During June to November inflow from Kotmale reservoir is higher than the remaining 


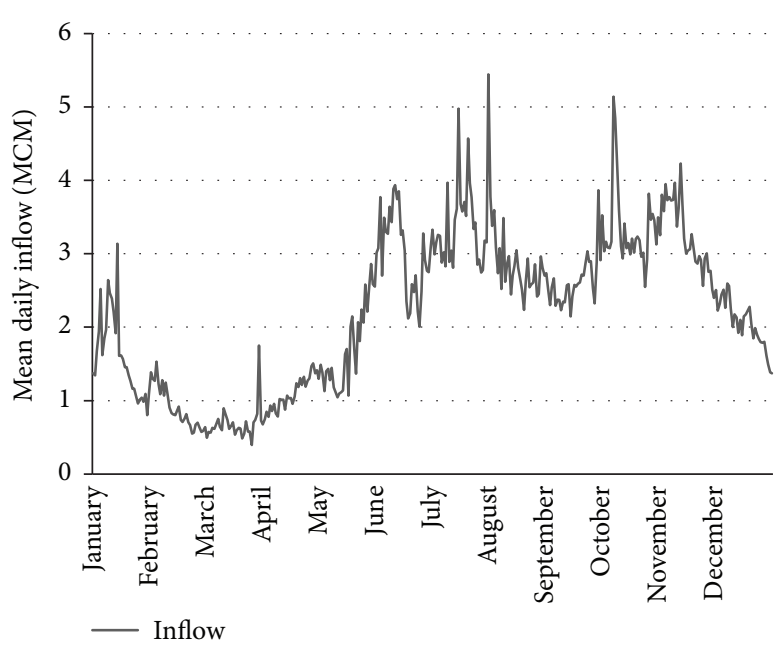

(a)

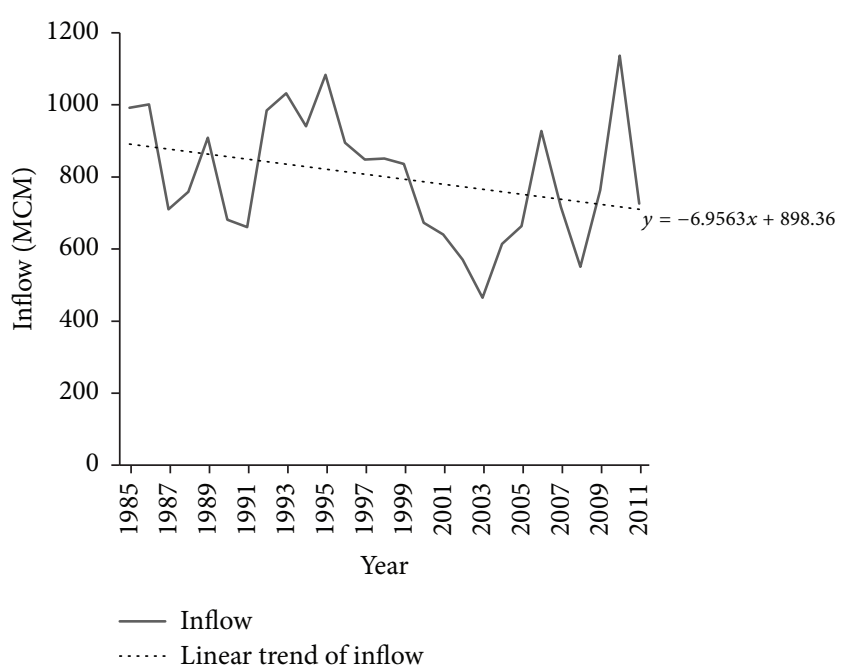

(b)

Figure 10: Daily mean inflow (MCM) (a) and annual change of the inflow (b) for Kotmale reservoir, Sri Lanka.

months of the year (Figure 10). Dilini et al. [26] identified that, starting from March, inflow to Kotmale reservoir steadily increases until July and then shows a slow decrease until October. As discussed in previous paragraphs the amount of rainfall received for the selected stations decreased with time (trend over years: 1985-2010) and due to this reason the inflow to the reservoir also exhibits a decreasing pattern.

September is the month when the main cultivation season (i.e., Maha season) starts in Sri Lanka. During Maha season almost up to $100 \%$ of rice cultivation is recommended by the relevant institutions. Therefore, one of the peak demands for stored water from the JJAS season arises during September. According to our results, there is a more likelihood to observe below average seasonal rainfall for JJAS season for the Kotmale catchment during warm ENSO phase than the other ENSO phases. Besides during warm ENSO phase, significant below average rainfall is also observed in the early September (Figure 9). Hence, the land preparation using onset of rainfall from the Northeast monsoon (i.e., September) and the cultivation of short term rice varieties and starting the cultivation on scheduled dates can be adopted during warm ENSO phase to mitigate the drought impact for the irrigated agriculture in downstream of the Kotmale reservoir.

Water demand for the hydropower generation is also impacted adversely during warm ENSO phase, due to the presence of below average rainfall. Therefore, mutually generating power with other sources is recommended to minimize the power failures during early September.

Domestic water requirement during warm ENSO phases can be mitigated by adopting scheduled water supply procedure. Water conservation methods and awareness should be spread to conserve the water.

Catchment protection is another long term drought mitigation procedure which can be applied for the Kotmale reservoir. Deforestation is also one of the reasons for the reduction of rainfall for some of the stations in the catchment area; therefore relevant institutions, that is, Department of
Forest Conservation, Sri Lanka, need to implement suitable remedies to minimize deforestation. Furthermore, it is advantageous to practice soil conservation methods for upper Kotmale catchment, because large tea plantations cover the upper Kotmale catchment and are neglected and the poorly managed estates have impact on the reservoir by siltation and eutrophication. These actions have led to reduction of quality and quantity of the stored volume of the reservoir [23].

\section{Conclusions}

Rainfall in Kotmale catchment showed both increasing in some stations and decreasing pattern in some other stations for JJAS season during 1960-2005 which is noticed. However, the increase in rainfall in the JJAS season has low influence on the annual rainfall of the selected stations because annual rainfall for the stations showed decreasing trend during the selected time period.

Kotmale catchment has a high likelihood of having below average rainfall for warm ENSO phase during JJAS season and rainfall during early September has a significant below average rainfall in the warm ENSO phase. However, during cold and neutral ENSO phases, Kotmale catchment did not show significant changes in the rainfall as it did in warm ENSO phase.

Although the Kotmale reservoir experiences high rainfall during JJAS, the annual rainfall showed decreasing trend. Therefore, it is vital to incorporate knowledge of teleconnection of ENSO phases over rainfall of the Kotmale catchment to implement effective water management strategy for the reservoir. There are other large persistent atmospheric oscillations, which can also influence the rainfall over Sri Lanka (i.e., Indian Ocean Dipole and Madden Julian Oscillation). Therefore we suggest that further studies are necessary to assess the impact of mentioned oscillations on the rainfall over the Kotmale reservoir in Sri Lanka. 


\section{Conflicts of Interest}

The authors declare that they have no conflicts of interest.

\section{Acknowledgments}

The authors would like to thank APEC Climate Center, Busan, for providing the necessary facilities to pursue this study. The work was done during the YSSP program by the first author under the supervision of second author at APEC Climate Center, Busan. The station datasets provided by the Sri Lanka Meteorological Department and Mahaweli Authority of Sri Lanka are duly acknowledged. This research was also supported by a Grant (16RDRP-B076564-03) from regional development research program funded by Ministry of Land, Infrastructure and Transport of Korean government.

\section{References}

[1] H. K. W. I. Jayawardene, D. U. J. Sonnadara, and D. R. Jayawardene, "Trends of rainfall in Sri Lanka over the last century," Sri Lankan Journal of Physics, vol. 6, pp. 7-17, 2005.

[2] C. F. Ropelewski and M. S. Halpert, "Global and Regional Scale Precipitation Patterns Associated with the El Niño/Southern Oscillation," Monthly Weather Review, vol. 115, no. 8, pp. 16061626, 1987.

[3] V. Prasanna, "South Asian Summer Monsoon Rainfall Variability and Trend: Its Links to Indo-Pacific SST Anomalies and Moist Processes," Pure and Applied Geophysics, vol. 173, no. 6, pp. 2167-2193, 2016.

[4] M. D. Dettinger and H. F. Diaz, "Global characteristics of stream flow seasonality and variability," Journal of Hydrometeorology, vol. 1, no. 4, pp. 289-310, 2000.

[5] E. M. Rasmusson and T. H. Carpenter, "The relationship between eastern equatorial Pacific sea temperature and rainfall over India and Sri Lanka," Monthly weather Review, vol. 115, pp. 1606-1626, 1983.

[6] L. Zubair, "El Niño-Southern oscillation influences on rice production in Sri Lanka," International Journal of Climatology, vol. 22, no. 2, pp. 249-260, 2002.

[7] L. Zubair, "Sensitivity of Kelani streamflow in Sri Lanka to ENSO," Hydrological Processes, vol. 17, no. 12, pp. 2439-2448, 2003.

[8] L. Zubair, "El Niño-southern oscillation influences on the Mahaweli streamflow in Sri Lanka," International Journal of Climatology, vol. 23, no. 1, pp. 91-102, 2003.

[9] V. Prasanna and T. Yasunari, "Interannual variability of atmospheric water balance over South Peninsular India and Sri Lanka during northeast monsoon season," International Journal of Climatology, vol. 28, no. 15, pp. 1997-2009, 2008.

[10] R. Suppiah, "Relationships between the Southern Oscillation and the rainfall of Sri Lanka," International Journal of Climatology, vol. 9, no. 6, pp. 601-618, 1989.

[11] R. Suppiah, "Extremes of the Southern Oscillation phenomenon and the rainfall of Sri Lanka," International Journal of Climatology, vol. 17, no. 1, pp. 87-101, 1997.

[12] B. A. Malmgren, R. Hulugalla, Y. Hayashi, and T. Mikami, "Precipitation trends in Sri Lanka since the 1870s and relationships to El Niño-southern oscillation," International Journal of Climatology, vol. 23, no. 10, pp. 1235-1252, 2003.
[13] C. F. Ropelewski and P. D. Jones, "An extensions of the TahitiDarwin Southern Oscillation Index," Monthly Weather Review, vol. 115, pp. 2161-2165, 1987.

[14] R. Suppiah, "Spatial and temporal variations in the relationships between the Southern Oscillation phenomenon and the rainfall of Sri Lanka," International Journal of Climatology, vol. 16, no. 12, pp. 1391-1407, 1996.

[15] K. K. Kumar, B. Rajagopalan, and M. A. Cane, "On the weakening relationship between the indian monsoon and ENSO," Science, vol. 284, no. 5423, pp. 2156-2159, 1999.

[16] R. Allen, J. Lindsey, and D. Parker, El-Nino Southern Oscillation and climate variability, CSIRO Publishing, Collingwood, Australia, 1996.

[17] L. Zubair, S. C. Rao, and T. Yamagata, "Modulation of Sri Lanka rainfall by the Indian Ocean Dipole," Geophysical research Letters, vol. 10, no. 2, pp. 1063-1066, 2003.

[18] L. Zubair and C. F. Ropelewski, "The strengthening relationship between ENSO and northeast monsoon rainfall over Sri Lanka and southern India," Journal of Climate, vol. 19, no. 8, pp. 1567$1575,2006$.

[19] W. L. Sumathipala, "El Nino - A short term signal of a long term and a large scale climate variation," Journal of the National Science Foundation of Sri Lanka, vol. 42, no. 3, pp. 173-174, 2014.

[20] R. Romesha, 2015, Hydro power generation. Kotmale power plant, http://www.slideshare.net/rasithap/kotmale-power-station.

[21] Mahaweli Authority of Sri Lanka. (n.d.). Kotmale, http://mahaweli.gov.lk/en/complete.html.

[22] Food and Agriculture Organization of the United Nation, The Mahaweli basin. In: Inland fisheries in multiple-purpose river basin planning and development in tropical Asian countries Three case studies. Eds. Petr. T., 1985, http://www.fao.org/ docrep/003/X6861E/X6861E00.htm\#TOC.

[23] D. Johansson, "The Kotmale environment. A study of the environment impact of the Kotmale Hydropower project in Sri Lanka. SIDA evaluation report 1989/1, Infrastructure, Sri Lanka," in Proceedings of the Swedish International Development Authority, K. Goppers, Ed., Stockholm, Sweden, 1989.

[24] R. L. Haturusinha and S. W. Ediriweera, "Maintenance and conservation of dams in Sri Lanka," in Proceedings of the Rehabilitation. Proceedings of the International Congress on Conservation and Rehabilitation of Dams, J. A. Llanos, J. Yague, F. Sanz de Ormijana, M. Cabrera, and J. S. Penas, Eds., pp. 11-13, Madrid, Spain, 2003.

[25] N. T. S. Wijesekera, Reservoir system in river Mahaweli, associated hydrology and flood behavior prior to and after development works, http://geoinfo.mrt.ac.lk/waterresources/ publications/D028.pdf.

[26] W. M. Dilini, L. Lyanage-Hansen, M. T. Attygalle, and K. D. Nandalal, "Effective Water Management in the Mahaweli Reservoir System: Analyzing the Inflow of the Upmost Reservoir," in Proceedings of the International Symposium for Next Generation Infrastructure, Wollongong, Australia, October, 2013.

[27] Dzone, Submerged ancient temple surfaces from Kotmale reservoir, 2011, https://blog.dzone.lk/2011/09/09/submergedancient-temple-surfaces-from-kotmale-reservoir/.

[28] J. Chandimala and L. Zubair, "Predictability of stream flow and rainfall based on ENSO for water resources management in Sri Lanka," Journal of Hydrology, vol. 335, no. 3-4, pp. 303-312, 2007.

[29] S. Chandrasekara and V. Prasanna, "MJO and ENSO interactions on monsoonal rainfall over Sri Lanka," in APEC Climate Center. Young Scientist Support Program 2012, pp. 474-499, 2013. 
[30] Wikipedia, Holmwood Estate, 2012, http://en.wikipedia.org/ wiki/Holmwood_Estate.

[31] Monogabey.com. (2006). Sri Lanka, http://rainforests.mongabay.com/deforestation/archive/Sri_Lanka.htm.

[32] P. Wickramagamage, "Spatial and temporal variation of rainfall trends of Sri Lanka," Theoretical and Applied Climatology, vol. 125, no. 3-4, pp. 427-438, 2016.

[33] Wikipedia, 1997-98 El Niño event, 2017, https://en.wikipedia .org/wiki/1997\%E2\%80\%9398_El_Ni\%C3\%Blo_event.

[34] P. M. Jayakody, The influence of La Nina on Sri Lanka rainfall, 2013, http://iesm.upd.edu.ph/wp-content/uploads/2017/02/ The-Influence-of-La-Nina-on-Sri-Lanka-Rainfall.pdf. 

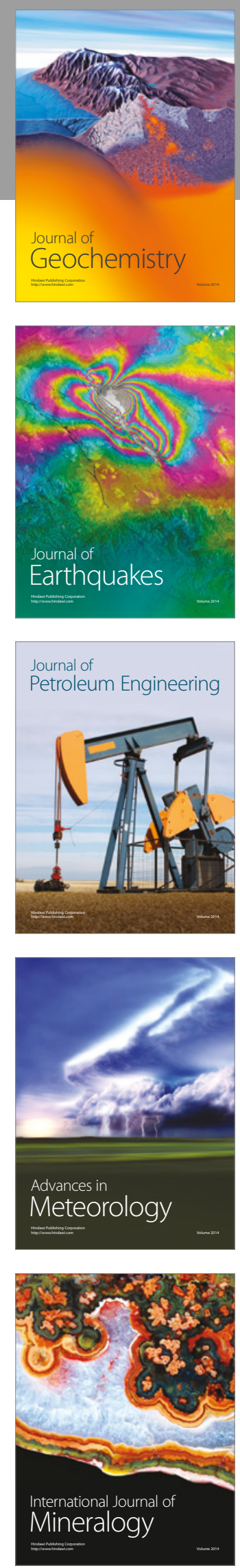
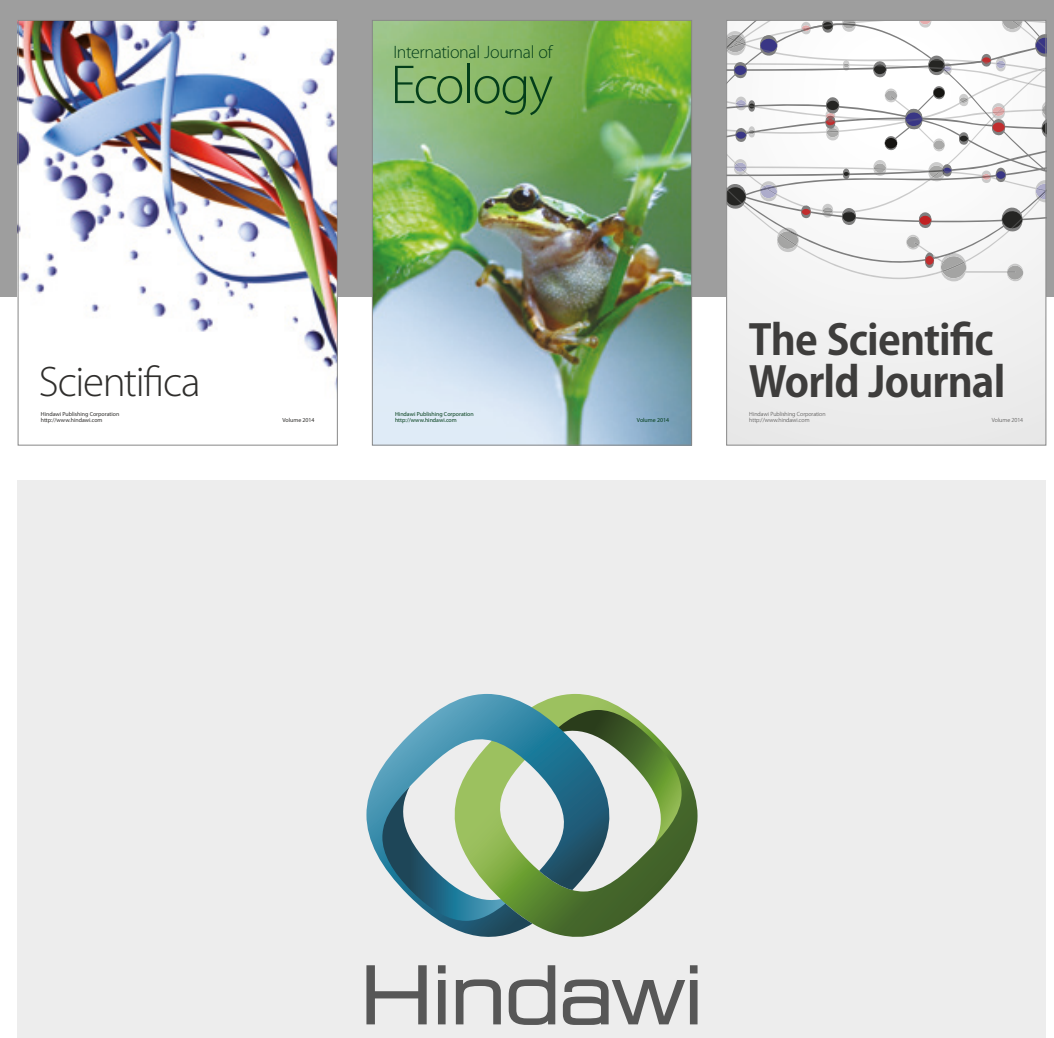

Submit your manuscripts at

https://www.hindawi.com
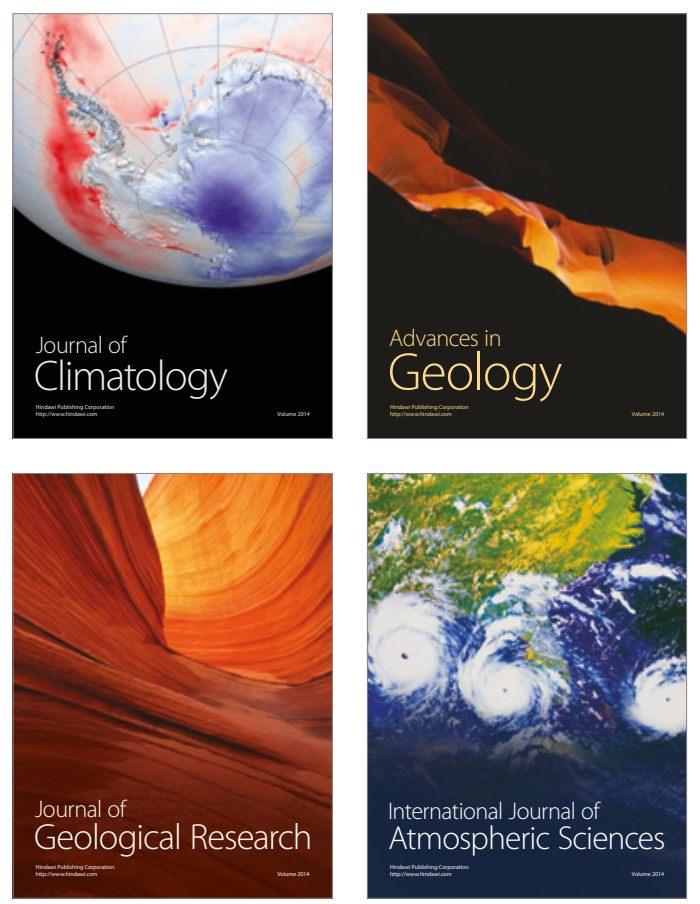

The Scientific

World Journal
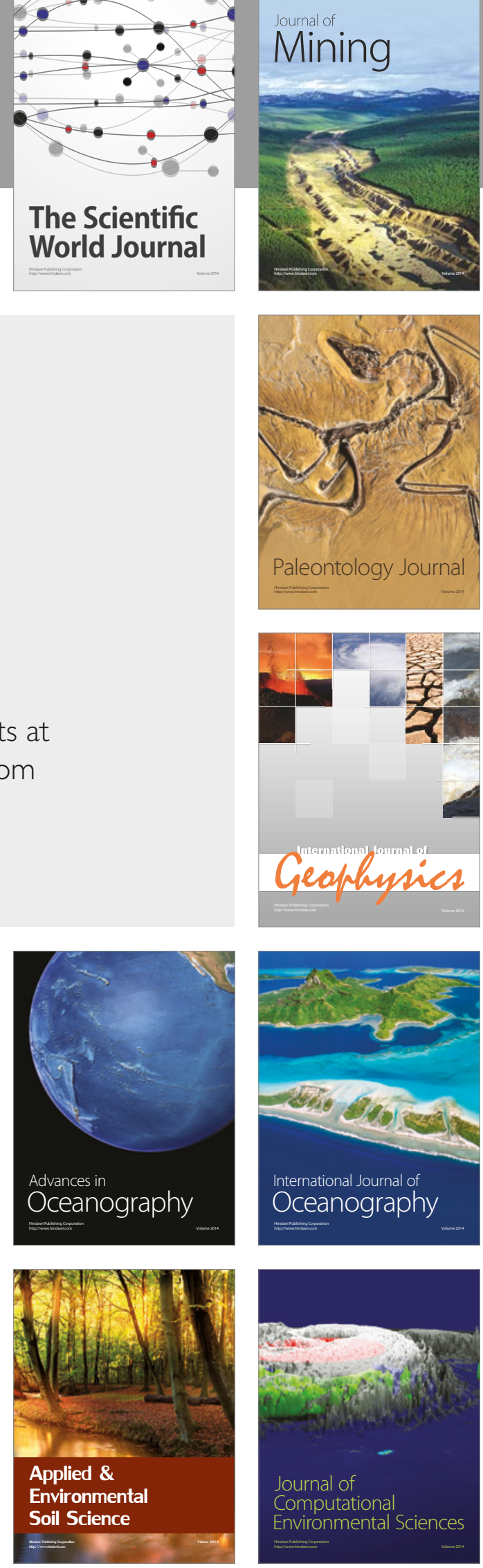